\title{
The Tea and Polysaccharide Fractions of Ximenia americana Stem Barks Inhibits Inflammatory Parameters Induced by Zymosan in Mice
}

\author{
Gabriela Fernandes Oliveira Marques \\ Superior Institute of Biomedical Science, StateUniversity of Ceará \\ Av. Dr. Silas Munguba 1700, 60740-000, Fortaleza-CE, Brazil. \\ Tel: +55 85988161543 E-mail: gabriela.fomarquesd@gmail.com
}

Arcelina Pacheco Cunha

Organic and Inorganic Chemistry Department, Federal University of Ceará, Av. Mister Hull s/n, bl 940, Campus do Pici, 60451-970, Fortaleza-CE, Brazil.

Tel: +55 85987333028 E-mail: arcelinapacheco@yahoo.com.br

Francisco Sávio Machado Lima Gabriel

Superior Institute of Biomedical Science, State University of Ceará

Av. Dr. Silas Munguba 1700, 60740-000, Fortaleza-CE, Brazil.

Tel: +55 85986269176 E-mail: savio.gabriel@ aluno.uece.br

Nágila Maria Pontes Silva Ricardo

Organic and Inorganic Chemistry Department, Federal University of Ceará, Av. Mister Hull s/n, bl 940, Campus do Pici, 60451-970, Fortaleza-CE, Brazil. Tel: +55 85986349432 E-mail: naricard@ufc.br

Maria Gonçalves Pereira

Faculty of Education, Sciences and Letters of the Sertão Central, State University of Ceará 
Rua José de Queirós Pessoa, 2554, 63900-000, Quixadá-CE, Brazil.

Tel: +55 85986092112 E-mail: mag_1299@yahoo.com

\author{
Ana Maria Sampaio Assreuy (Corresponding author) \\ Superior Institute of Biomedical Science, State University of Ceará \\ Av. Dr. Silas Munguba 1700, 60740-000, Fortaleza-CE, Brazil. \\ Tel: +55 85988236030 E-mail: anassreuy@ gmail.com
}

Received: August 16, 2020 Accepted: Sep. 14, 2020

doi:10.5296/jbls.v11i2.17698 URL: https://doi.org/10.5296/jbls.v11i2.17698

\begin{abstract}
Ximenia americana or "ameixa-do-sertão" is a plant used in the folk medicine of Northeast-Brazil in inflammatory and painful processes. The literature has shown anti-inflammatory and antinociceptive activities for the aqueous or hydroalcoholic extracts and polysaccharide fractions of $X$. americana stem barks. This study investigated the anti-inflammatory effect of polysaccharide fractions and tea prepared from $X$. americana stem barks in mice models of paw edema and peritonitis induced by zymosan. Tea $(50,100$, $150 \mathrm{mg} / \mathrm{kg}$; p.o.) and polysaccharide fractions (FI, FII: $1 \mathrm{mg} / \mathrm{kg}$; i.v.), containing carbohydrate $(44.8,25.0,44.4 \%)$ and polyphenols $(28.3,0.78,1.50 \%)$, respectively, were administered $1 \mathrm{~h}$ before zymosan $(500 \mu \mathrm{g}$; s.c. or i.p). FT-IR analysis of the tea showed bands indicating $\mathrm{C}=\mathrm{O}$ and $\mathrm{C}-\mathrm{O}$ groups vibration, typical of phenolic compounds. Zymosan-induced paw edema (AUC: $355.0 \pm 38.1$ ) was inhibited by the tea by $38 \%(100 \mathrm{mg} / \mathrm{kg})$ and $36 \%(150$ $\mathrm{mg} / \mathrm{kg}$ ). FI and FII reduced the edema by 47\% (933.8 \pm 158.1 AUC) and 30\% (1263 \pm 124.8 AUC), respectively. Zymosan i.p. induced hypernociception ( $4.7 \pm 0.3 \mathrm{~g})$ and increased the peritoneal leukocyte migration $(10979 \pm 1475$ cells $/ \mu \mathrm{l})$. FII increased by $66 \%$ the nociceptive threshold $(13.87 \pm 1.59 \mathrm{~g})$ and reduced by $63 \%$ leukocyte migration $(3993 \pm 439.1 \mathrm{cells} / \mu \mathrm{l})$. FII decreased plasma protein by $64 \%(92.6 \pm 4.5 v s$. zymosan: $119.6 \pm 5.4 \mu \mathrm{g} / \mathrm{ml})$ and MDA by $63 \%(57.5 \pm 3.5 v s$. zymosan: $88.9 \pm 6.3 \mu \mathrm{g} / \mathrm{ml})$. The tea, containing polysaccharides and polyphenols, and polysaccharide fractions FI/FII of $X$. americana barks possess antiinflammatory effect in mice models of acute inflammation induced by zymosan.
\end{abstract}

Keywords: medicinal plant, Ximenia americana, polysaccharides, decoction

\title{
1. Introduction
}

Natural compounds isolated from medicinal plants have been widely investigated due to its anti-inflammatory and analgesic properties, allowing the validation of the popular use and directing several clinical researches. These compounds can be obtained from various plant 
parts, such as stem barks, leaves, fruits, seeds, roots, and are popularly used as infusion, maceration, decoction, etc (Balunas \& Kinghorn, 2005).

Among plant compounds, polysaccharides are highly bioavailable and have low or no toxicity (Ovodov, 1998). Regarding its biological activities in the inflammatory process, the polysaccharide fractions obtained from pods of Caesalpinia ferrea (jucá) and seeds of Azadirachta indica (neem) inhibited leukocyte migration and acute phase inflammatory mediators in rats (Pereira et al., 2012a; 2012b). In nociceptive processes, Thladiantha dubia fruit polysaccharides reduced the abdominal contortions elicited by acetic acid (Wang et al., 2011).

Ximenia americana L. (Olacaceae), popularly known as ameixa-do-sertão, is widely distributed in Northeast Brazil (Le et al., 2012), being its barks prepared as decoction ("tea") to treat inflammatory and painful conditions. Experimental studies demonstrated the antiinflammatory effect for the hydroethanolic bark extracts in acute and chronic inflammation models (da Silva et al., 2018). The aqueous extract of $X$. americana roots reduced paw edema, neutrophil migration and vascular permeability induced by carrageenan in mice (Olabissi et al., 2011). The antinociceptive activity of the aqueous extract obtained from stem barks was also demonstrated in the inflammatory phase of the formalin test (Soro et al., 2009). In addition, total polysaccharide and fractions isolated from $X$. americana presented inhibitory effect in inflammatory models (Silva-Leite et al., 2017, 2018). Moreover, the inhibitory effect on neutrophil migration was demonstrated in the gastritis model for the tea of $X$. americana, prepared following the same protocol used in the present study (da Silva-Pantoja et al., 2018).

This study aimed to evaluate the anti-inflammatory activity of the tea and polysaccharides obtained from $X$. americana stem barks in the models of paw edema and peritonitis induced by zymosan in mice.

\section{Material and Methods}

\subsection{Experimental Design}

The anti-inflammatory and anti-hypernociceptive activities of the tea preparation and polysaccharide fractions of $X$. americana stem barks were evaluated after stimulation of mice paws or peritonium with the flogistic agent zymosan for analysis of the following parameters: edema, protein leakage, leukocyte infiltrate, oxidative stress markers (malondialdehyde) and hyperalgesia. Control animals received sterile saline by subcutaneous (s.c.) route in the paws or intraperitoneal (i.p.).

\subsection{Material}

\subsubsection{Plant}

Barks of X. americana were collected in Custódio county (Quixadá-CE) and the plant exsiccate was deposited at FECLESC/Quixadá and Herbarium Prisco Bezerra - UFC ( $n^{\circ}$ 46794). In accordance to the Brazilian Federal Law No. 13123/2015, the assessment activity was registered in the Brazilian System for the Management of the Genetic Heritage and the Associated Traditional Knowledge (SISGEN - A8B2C79). 
2.2.2 Tea Preparation, Extraction and Isolation of Polysaccharides of X. americana

The tea was obtained by decoction of $X$. americana stem barks in distilled water $\left(100^{\circ} \mathrm{C} / 5 \mathrm{~min}\right)$ and lyophilization before used in the experimental protocols (da Silva-Pantoja et al., 2018).

For the polysaccharides extraction and isolation, barks were washed, dried $\left(40^{\circ} \mathrm{C}\right)$ and macerated into powder $(5 \mathrm{~g})$, suspended in methanol $(1: 50, \mathrm{w} / \mathrm{v})$, homogenized $\left(76^{\circ} \mathrm{C}, 2 \mathrm{~h}\right)$ and filtered $(2 \mathrm{x})$. The insoluble portion was added to $0.1 \mathrm{M} \mathrm{NaOH}\left(97{ }^{\circ} \mathrm{C}, 2 \mathrm{~h}\right)$, filtered and centrifuged $(2496 \mathrm{~g}$, $\left.15 \mathrm{~min}, 25^{\circ} \mathrm{C}\right)$. The alkaline supernatants were neutralized $(1 \mathrm{M} \mathrm{HCl})$, precipitated in ethanol and centrifuged under the previous conditions. The final precipitate was dialyzed and the supernatant centrifuged (Silva-Leite et al., 2017), which was precipitated with trichloroacetic acid (TCA) until reaching $\mathrm{pH} 2.0$ or 3.0, over $4 \mathrm{~h}$ in ice bath $\left(4^{\circ} \mathrm{C}\right)$ (Zhao et al., 2014). The protein precipitate was separated by centrifugation $\left(2496 \mathrm{~g}, 30 \mathrm{~min}, 25^{\circ} \mathrm{C}\right.$ ) and the supernatant dialyzed and lyophilized to obtain the total polysaccharides deproteinized, named TPL-Xa.

2.2.3 Fractioning, Biochemical and Structural Caracterization of Tea and Polysaccharides of $X$. americana

TPL-Xa was dissolved in distilled water (1:2, w/v) and applied to chromatographic column (resin: DEAE-cellulose), equilibrated and washed with distilled water, and eluted with $\mathrm{NaCl}$ $(0.1$ and $0.25 \mathrm{M})$. Polysaccharide fractions were monitored for the carbohydrate content by the phenol-sulfuric acid method (Silva-Leite et al., 2017; Dubois et al., 1956).

Tea and polysaccharide fractions were quantified for total carbohydrate (Dubois et al., 1956), hexoses and hexuronic acid (Dische, 1947), total protein (Bradford, 1976), and polyphenolic compounds (Siddiqui et al., 2017), in comparison with standard curves of galactose, galacturonic acid, bovine serum albumin and gallic acid, respectively.

The tea was analyzed by infrared spectroscopy (FT-IR). For this, samples $(2 \mathrm{mg}$ ) were mixed with powdered potassium bromide and pressed into a disc in the medium infrared region at $500-4000 \mathrm{~cm}^{-1}$, with resolution of $3 \mathrm{~cm}^{-1}$ (Perkin Elmer Spectrum 100, USA).

\subsection{Experimental Protocols}

\subsubsection{Animals}

Swiss mice (25-35 g) were maintained with free Access to food and water and controlled environmental conditions (12/12 h light/dark cycle, temperature of $\left.25^{\circ} \mathrm{C}\right)$. The experimental protocols were approved by the Animal Care and Use Committee of the State University of Ceara (UECE n ${ }^{\circ}$ : 4153018/2018).

\subsubsection{Animals Treatment}

Decoction of $X$. americana barks $(50,100,150 \mathrm{mg} / \mathrm{kg}$ ) was administered per oral (p.o.) and the polysaccharide fractions FI $(0.1 \mathrm{M})$ and FII $(0.25 \mathrm{M})$ injected intravenously $(1 \mathrm{mg} / \mathrm{kg}$; i.v. $)$ $1 \mathrm{~h}$ before edema or peritonitis induction by zymosan.

\subsubsection{Paw Edema Model}

Paw edema was induced by zymosan $(500 \mu \mathrm{g}$; s.c. $)$ and measured by hydroplethysmometry at 
zero time and selected time intervals thereafter $(0.5,1-5 \mathrm{~h})$. Control animals received saline $(0.1 \mathrm{~mL} / 10 \mathrm{~g}$ body mass). Results were expressed as the variation in paw volume $(\mu \mathrm{l})$ or area under curve (AUC).

\subsubsection{Peritonitis Model}

Zymosan (500 $\mu \mathrm{g} /$ cavity) or saline was administered via intraperitoneal (i.p.) $4 \mathrm{~h}$ before hypernociception measurement. Immediately after euthanasia peritoneal fluid was harvested with $3 \mathrm{ml}$ saline (5 IU heparin) for total and differential leukocyte count (neutrophils and mononuclear cells) and quantification of total protein (Bradford, 1976) and malondialdehyde-MDA (TBARS) (Huong et al., 1998).

For evaluation of mechanical visceral hypernociception, mice were placed in clear acrylic box $15 \mathrm{~min}$ before the test for adaptation to the environment. The nociceptive threshold of the animals was tested by application of a gradual pressure (g) using polypropylene tip, coupled to a hand-held force transducer (Electronic Von Frey Anesthesiometer; Insight). Hypernociception was also evaluated at baseline (time zero) (Le Bars et al., 2001).

\subsection{Statistical Analysis}

Results were presented as mean \pm SEM. Analysis of variance (ANOVA) followed by Bonferroni's test were applied. P values $<0.05$ were considered significant.

\section{Results}

\subsection{Tea Preparation, Purification and Partial Chemical Characterization of Polysaccharides of $X$. americana Barks}

The tea prepared by decoction of $X$. americana barks revealed $1.8 \%$ yield, presenting carbohydrate (44.8\%, including $10.4 \%$ uronic acid) and polyphenols $(28.3 \%$ ) as major constituents, but low content of proteins (1.34\%). TPL-Xa (2.0 yield) was extracted from $X$. americana barks by the combination of light alkaline solution followed by precipitation with ethanol. The deproteinated TPL-Xa and major polysaccharide fractions, obtained by DEAE-cellulose, presented similar content of carbohydrate, specially TPL-Xa and FII (TPL-Xa: 43\%; FI: 25\%; FII: 44\%), but different content of uronic acid (TPL-Xa: 5.2\%; FI: 9.8\%; FII: 25\%), proteins (TPL-Xa: 0.6\%; FI: 0.9\%; FII: 0.8\%), showing relevant decrease in the polyphenols content (TPL-Xa: 4.64; FI: 0.78; FII: $1.50 \mathrm{GAE}$ ) compared to the tea. In addition, the uronic acid/hexoses ratio (0.56) was higher for FII (Table1).

Table 1. Yield and chemical analysis of $X$. americana tea and deproteinated polysaccharide fractions

\begin{tabular}{ccccccc}
\hline Samples & $\begin{array}{c}\text { Yield } \\
(\%)\end{array}$ & $\begin{array}{c}\text { ac } \text { Carbohydrates } \\
(\%)\end{array}$ & $\begin{array}{c}\text { b Uronicacid } \\
(\%)\end{array}$ & 'Uronicacid/Hexoses & $\begin{array}{c}\text { d Polyphenols } \\
(\text { GAE) }\end{array}$ & $\begin{array}{c}\text { 'Proteins } \\
(\%)\end{array}$ \\
\hline Tea & 1.8 & 44.8 & 10.4 & 0.23 & 28.3 & 1.34 \\
TPL-Xa & 2.0 & 43.0 & 5.2 & 0.12 & 4.64 & 0.6 \\
FI & 9.0 & 25.0 & 9.8 & 0.39 & 0.78 & 0.9 \\
FII & 34.0 & 44.4 & 25.0 & 0.56 & 1.50 & 0.8 \\
\hline
\end{tabular}




\section{IIl Macrothink Institute ${ }^{\text {TM }}$}

${ }^{\mathrm{a}}$ Dubois et al., 1956; ${ }^{\mathrm{b}}$ Dische 1947; ${ }^{\mathrm{c}}$ Molar ratio; ${ }^{\mathrm{d}}$ Siddiqui et al., 2017; ${ }^{\mathrm{e}}$ Bradford, 1976. GAE: gallic acid equivalent $(\mathrm{mg} / \mathrm{g})$. Yield: from $5 \mathrm{~g}$ dry poder of $X$. americana barks.

FTIR spectra of $X$. americana tea revealed absorption peaks around $3375 \mathrm{~cm}^{-1}$ and $2925 \mathrm{~cm}^{-1}$ corresponding to stretching of O-H and C-H, respectively (Sun et al., 2009). Peaks at $1442 \mathrm{~cm}^{-1}$, $1525 \mathrm{~cm}^{-1}$ and $1612 \mathrm{~cm}^{-1}$ were also detected, indicating presence of uronic acid (group COOH) (LI et al., 2014). Absortion regions between 1500 and $700 \mathrm{~cm}^{-1}$ correspond to carbohydrate range (Karnik et al., 2016), in which peak at $1113 \mathrm{~cm}^{-1}$, characterizes glycosidic bonds (Xu et al., 2016). The peak observed at $1442 \mathrm{~cm}^{-1}$ was attributed to the elongation of the $\mathrm{C}=\mathrm{O}$ group of aromatic rings, typical of phenolic compounds and the peak at $1296 \mathrm{~cm}^{-1}$ to $\mathrm{C}-\mathrm{O}$ in the flavonoids found in the tea (Bagheri et al., 2013) (Figure 1).

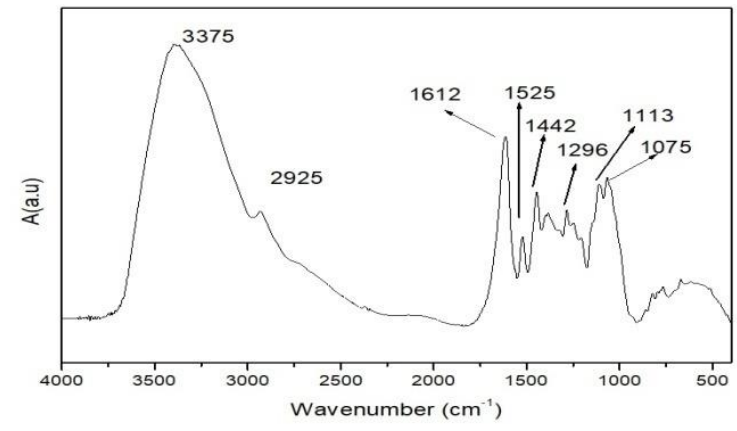

Figure 1. X. americana tea analysis by infrared spectroscopy (FTIR)

The spectral region examined was from 500 to $4000 \mathrm{~cm}^{-1}$, with resolution of $3 \mathrm{~cm}^{-1}$.

\subsection{Edematogenic Effect of Tea and Polysaccharides From X. Americana Barks}

Zymosan subcutaneous injection $(500(\mu \mathrm{g})$ induced paw edema, that reached maximal effect 3 $\mathrm{h}$ after induction $(211.4 \pm 24.1$ ( $\mu \mathrm{l} v$ s. saline: $2.5 \pm 2.5(\mu \mathrm{l})$, and was sustained until $5 \mathrm{~h}$. The animals treatment with tea preparation of $X$. americana showed better inhibition of edema at 3 h by $43 \%(100 \mathrm{mg} / \mathrm{kg}: 120.0 \pm 10.2(\mu \mathrm{l})$ and $40 \%(150 \mathrm{mg} / \mathrm{kg}: 131.4 \pm 15.3(\mu \mathrm{l})$ (Figure $2 \mathrm{~A})$. The area under curve $(2-4 \mathrm{~h})$ revealed that the tea at $150 \mathrm{mg} / \mathrm{kg}$ and $100 \mathrm{mg} / \mathrm{kg}$ reduced the zymosan-elicited edema (355.0 \pm 38.1 AUC vs. saline: $4.2 \pm 4.2$ AUC) by $38 \%(222.5 \pm 18.7$ AUC) and 36\% (229.2 \pm 15.6 AUC), respectively (Figure 2B). FI and FII (1 mg/kg) reduced the edema at $2 \mathrm{~h}$ by $55 \%(38.7 \pm 6.9$ ( $\mu \mathrm{l} v s$. zymosan: $86.6 \pm 9.5 \quad(\mu \mathrm{l})$ and $65 \%(30.0 \pm 6.6(\mu \mathrm{l} v s$. zymosan: $86.6 \pm 9.5$ ( $\mu \mathrm{l}$ ) (Figure 2C). The area under curve showed that FI and FII reduced the edema by 47\% (933.8 \pm 158.1 AUC) and 30\% (1263 \pm 124.8 AUC), respectively (Figure 2D). 

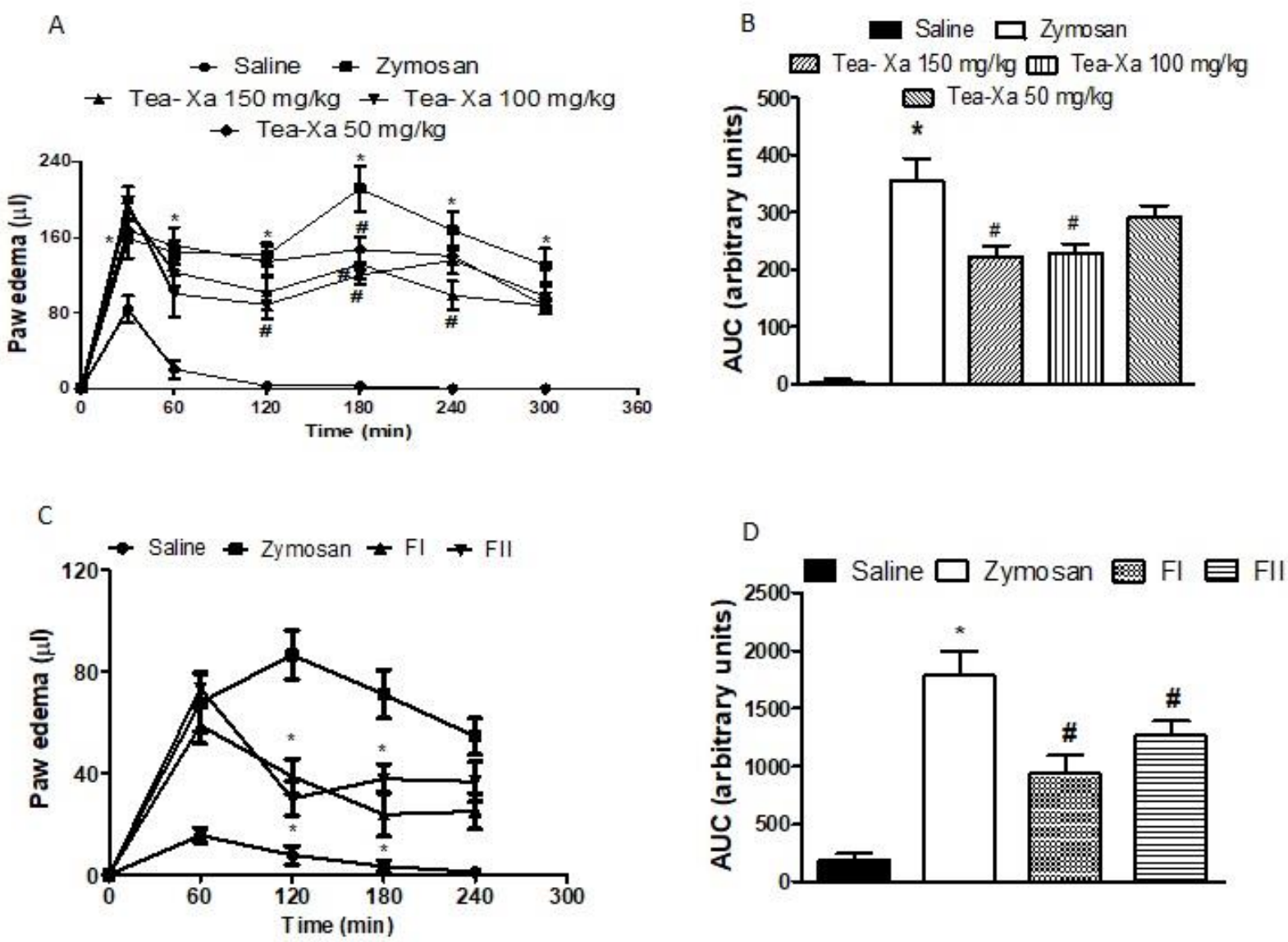

Figure 2. Inhibitory effect of the tea preparation and polysaccharide fractions (FI e FII) on zymosan-induced edema

(A) Mice were treated with tea (50, 100, $150 \mathrm{mg} / \mathrm{kg}$; p.o.) or (C) FI and FII (1 mg/kg) $1 \mathrm{~h}$ after zymosan (500 ( $\mu \mathrm{g} / \mathrm{paw}, \mathrm{s.c})$; control animals received saline. Edema was evaluated by hidropletysmometry after (1-5 h) and before treatment (B, D) Area under curve. Mean \pm SEM $(\mathrm{n}=8)$. ANOVA and Bonferroni * $\mathrm{p}<0.05$ vs. saline \# $<00.05$ vs. zymosan.

3.3 FII Inhibits Inflammatory Parameters and Oxidative Stress Makers in the Peritonitis Induced

Zymosan i.p. (500 $(\mu \mathrm{g})$ elicited hypernociception in mice, observed by the behavioral response of abdomen withdrawal in response to the pressure applied, reducing the nociceptive threshold compared to the control (zymosan: $4.7 \pm 0.3 \mathrm{~g} v s$. saline: $14.7 \pm 0.9 \mathrm{~g}$ ). FII increased by $66 \%$ the animal's nociceptive threshold, restoring the values close to the controls (FII: $13.87 \pm 1.59$ ) (Figure 3A). 


\section{Macrothink}

Journal of Biology and Life Science ISSN 2157-6076 2020, Vol. 11, No. 2

Zymosan i.p. (500 ( $\mu \mathrm{g})$ also increased in 5 fold the number of total leukocytes/ $(\mu \mathrm{l}$ in the animals peritoneum $(10979 \pm 1475$ cells $/(\mu \mathrm{l} v s$. saline: $2106 \pm 266.7$ cells $/(\mu \mathrm{l})$. FII treatment reduced by $63 \%$ total leukocytes $(3993 \pm 439.1$ cells/ $(\mu \mathrm{l})$, mainly neutrophils, by $82 \%$ (1350 \pm 238.9 vs. zymosan: $7773.2 \pm 1191$ cells $/(\mu \mathrm{l})$ (Figure 3B). Besides, FII decreased plasma protein by $64 \%$ (92.6 \pm 4.5 vs. zymosan: $119.6 \pm 5.4(\mu \mathrm{g} / \mathrm{ml})$ (Figure 3C) and MDA by 63\%
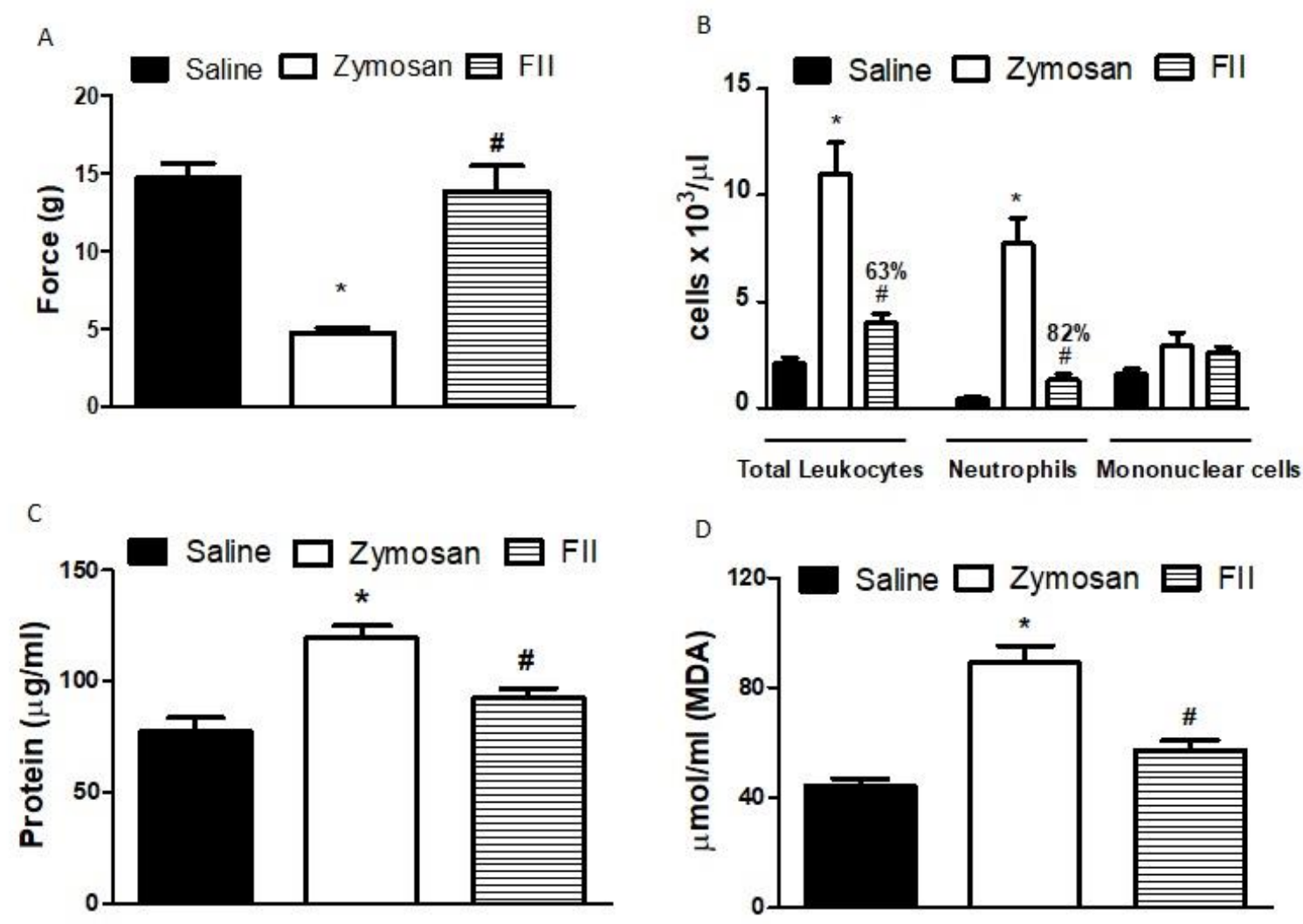

(57.5 \pm 3.5 vs. zymosan: $88.9 \pm 6.3 \mathrm{~g} / \mathrm{ml})$ (Figure 3D).

Figure 3. Inhibitory effect of the polysaccharide fraction FII on inflammatory parameters induced by zymosan

Mice were treated with FII ( $1 \mathrm{mg} / \mathrm{kg}) 1 \mathrm{~h}$ after zymosan $(500$ ( $\mu \mathrm{g} /$ cavity, i.p.); control animals received saline. Inflammatory parameters were assessed in the peritoneal fluid $4 \mathrm{~h}$ after stimuli (A) Abdominal hypernociception; (B) total and differential leukocyte; (C) Protein; (D) MDA. Mean \pm SEM $(n=8)$. ANOVA and Bonferroni * $\mathrm{p}<0.05$ vs. saline. \# $\mathrm{p}<0,05$ vs. zymosan.

\section{Discussion}

The present study demonstrates the obtention and partial chemical characterization of deproteinized polysaccharide fractions and tea from $X$. americana stem barks, along with its anti-inflammatory activity in the mice models of paw edema and peritonitis induced by zymosan. 
The tea presented high content of total carbohydrates and polyphenols with low protein content. Previous studies had already demonstrated this biochemical pattern in teas and polysaccharide fractions obtained from plants (Zhu et al., 2019, Yang et al., 2018, Chen et al., 2018).

TPL-Xa and FII fraction presented carbohydrate content similar to the tea, but different uronic acid content, being FII superior in the ratio uronicacid/hexoses, and substantial lower levels of polyphenols compared to the tea. It is well reported in the literature that polysaccharide fractions of several plants present similar biochemical composition compared to the decoction extracts (teas) from which they were extracted (Chen et al., 2016).

The tea FTIR spectra demonstrates peaks related to carbohydrate range, uronic acid (group $\mathrm{COOH}$ ), phenolic compounds and flavonoids (Sun et al., 2009; Karnik et al., 2016; Li et al., 2014; Bagheri et al., 2013). Our data reinforce the suggestion that despite of different extraction methods the total carbohydrates content does not significantly change. These results corroborate the absorption ranges found for the non-deproteinated FII fraction extracted from $X$. americana barks, already published by our research group (Silva-Leite et al., 2017).

The animal's treatment p.o. with the tea and i.v. with the polysaccharide fractions of $X$. americana inhibited the zymosan-induced paw edema. Zymosan, a polysaccharide of yeast cell wall, induces an inflammatory response involving dose and time-dependent edema, accompanied by severe leukocyte infiltrate (Suo et al., 2014). Studies had shown the antiedematogenic effect of plant polysaccharide extracts, such as those from Caesalpinea ferrea, Azadirachta indica (Pereira et al., 2012a; 2012b) and X. americana (roots aquous etanol extract) (Olabissi et al., 2011) in carrageenan-induced edema, which is also accompanied by protein exudate and intense leukocyte infiltrate (DiRosa et al., 1971).

Zymosan, administered i.p. induces acute inflammation characterized by severe leukocyte infiltrate, increase in vascular permeability, hypernociception and inflammatory mediators (Leite et al., 2015). The animal's treatment with FII reduced neutrophil migration and vascular permeability, seen by the decrease in protein leakage, and also increased the abdominal nociceptive threshold, showing significant action on inflammatory pain. In previous studies, similar results had been reported for other plant polysaccharides (Pereira et al., 2012a; 2012b; Wang et al., 2011; Olabissi et al., 2011; Silva-Leite et al., 2017).

Moreover, our results showed that the polysaccharide fraction FII was able to reduce MDA levels in the peritoneal fluid of animals stimulated with zymosan. Malondialdehyde is one of the main product of lipid peroxidation, therefore an important oxidative stress determinant in clinical situations, such as inflammation (Giera et al., 2012). Accordingly, antioxidant and free- radical scavenging activities had been described for plant polysaccharides (Chen et al., 2004; Liu et al., 2011; Mengome et al., 2014; Lin et al., 2017).

The chemical analysis showed high carbohydrate content in the tea and polysaccharide fractions composition, especially FII, which reinforce the supposition that both the anti-inflammatory effect of tea and fractions, as well as the antioxidant effect of FII may be accounted for the polysaccharides. In addition, the tea also presents considerable content of 
polyphenols, substance well described for its anti-inflammatory and antioxidant properties (Xu et al., 2017).

In conclusion, the polysaccharide fractions and the tea, containing polysaccharides and polyphenols, obtained from $X$. americana stem barks possess anti-inflammatory effect in the mice models of paw edema and peritonitis induced by zymosan via reduction of edema, protein exudate, neutrophil migration and inflammatory pain. These effects may validate the popular use of $X$. americana as anti-inflammatory.

\section{Acknowledgements}

This work was supported by grants from CNPq and FUNCAP. AMS Assreuy is sênior investigator of CNPq (Process No. 308433/2017-3).

\section{References}

Bagheri, L., Madadlou, A., Yarmand, M., \&Mousavi, M. E. (2013). Nanoencapsulation of date palm pit extract in whey protein particles generated via desolvation method. Food Res. Int., 51(2), 866-871. https://doi.org/10.1016/j.foodres.2013.01.058

Balunas, M. J., \&Kinghorn, A. D. (2005). Drug Discovery from medicinal plants. Life Sciences, 78(5), 431-441. https://doi.org/10.1016/j.lfs.2005.09.012

Bradford, M. M. (1976). A rapid and sensitive method for the quantitation of microgram quantities of protein utilizing the principle of protein-dye binding. Anal. Biochem., 72(1-2), 248-254. https://doi.org/10.1016/0003-2697(76)90527-3

Chen, G., Chen, R., Chen, D., Ye, H., Hu, B., Zeng, X., \& Liu, Z. (2018). Tea polysaccharides as potential therapeutic options for metabolic diseases. J. Agr. Food Chem. https://doi.org/10.1021/acs.jafc.8b05338

Chen, G., Yuan, Q., Saeeduddin, M., Ou, S., Zeng, X., \& Ye, H. (2016). Recentadvances in teapolysaccharides: Extraction, purification, physicochemical characterization and bioactivities. Carbohydr. Polym., 153, 663-678. https://doi.org/10.1016/j.carbpol.2016.08.022

Chen, H., Zhang, M., \& Xie, B. (2004). Quantification of Uronic Acids in Tea Polysaccharide Conjugates and Their Antioxidant Properties. J. Agric. Food. Chem., 52(11), 3333-3336. https://doi.org/10.1021/jf0349679

Da Silva Pantoja, P., Assreuy, A. M. S., Silva, R. O., Damasceno, S. R. B., Mendonça, V. A., Mendes, T. S., ... Soares, P. M. G. (2018). The polysaccharide-rich tea of Ximenia americana barks prevents indomethacin-induced gastrointestinal damage via neutrophil inhibition. $J$. Ethnopharmacol., 224, 195-201. https://doi.org/10.1016/j.jep.2018.05.041

Da Silva, B. A. F., da Costa, R. H. S., Fernandes, C. N., Leite, L. H. I., Ribeiro-Filho, J., Garcia, T. R., ... de Menezes, I. R. A. (2018). HPLC profile and antiedematogenic activity of Ximenia americana L. (Olacaceae) in mice models of skin inflammation. Food Chem. Toxicol., 119, 199-205. https://doi.org/10.1016/j.fct.2018.04.041

DiRosa, M., Giroud, J. P., \&Willoughby, D. A. (1971). Studies of the mediators of the acutei 
nflammatory response induced in rats in different sites by carrageenan and turpentine. $J$. Pathol., 104(1), 15-29. https://doi.org/10.1002/path.1711040103

Dische, Z. (1947). A specific color reaction for glucuronic acid. J. Biol. Chem., 171(2), 725-730.

DuBois, M., Gilles, K. A., Hamilton, J. K., Rebers, P. A., \& Smith, F. (1956). Colorimetric Method for Determination of Sugars and Related Substances. Anal. Chem., 28(3), 350-356. https://doi.org/10.1021/ac60111a017

Giera, M., Lingeman, H., \&Niessen, W. M. A. (2012). Recent Advancements in the LC- and GC-Based Analysis of Malondialdehyde (MDA): A Brief Overview. Chromatographia, 75(9-10), 433-440. https://doi.org/10.1007/s10337-012-2237-1

Huong, N. T.https://pubmed.ncbi.nlm.nih.gov/9781851/ - affiliation-1, Matsumoto, K., Kasai, R., Yamasaki, K., \& Watanabe, H. (1998). In vitro antioxidante activity of Vietnamese ginseng saponin and its components. Biol. Pharm. Bull., 21(9), 978-981. https://doi.org/10.1248/bpb.21.978

Karnik, D., Jung, J., Hawking, S., \& Wicker, L. (2016). Sugar beet pectin fractionated using isopropanol differs in galacturonic acid, protein, ferulic acid and surface hydrophobicity. Food Hydrocolloids, 60, 179-185. https://doi.org/10.1016/j.foodhyd.2016.03.037

Le Bars, D., Gozariu, M., \& Cadden, S. (2001). Animal Models of Nociception. Pharmacol. Rev., 53, 597-652.

Le, N. H. T., Malteruda, K. E. L., Diallo, D., Paulsen, B. S., Nergårda, C. S., \& Wangensteen, H. (2012). Bioactive polyphenols in Ximenia americana and the traditional use among $\begin{array}{llll}\text { Malianhealers. } & J & \text { Ethnopharmacol. } & \text { 139(3), }\end{array}$ https://doi.org/10.1016/j.jep.2011.12.031

Leite, J. A., Alves, A. K. D. A., Galvão, J. G. M., Teixeira, M. P., Cavalcante-Silva, L. H. A., Scavone, C., ... Rodrigues-Mascarenhas, S. (2015). Ouabain Modulates Zymosan-Induced Peritonitis in Mice. Mediat. Inflamm., 2015, 1-12. https://doi.org/10.1155/2015/265798

Li, X., Jiang, J., Shi, S., Bligh, S. W. A., Li, Y., Jiang, Y., ... Wang, S. (2014). A RG-II Type Polysaccharide Purified from Aconitum coreanum Alleviates Lipopolysaccharide-Induced

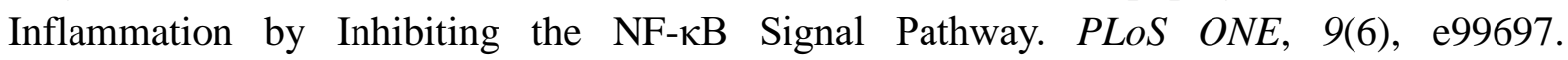
https://doi.org/10.1371/journal.pone.0099697

Lin, L., Xie, J., Liu, S., Shen, M., Tang, W., \&Xie, M. (2017). Polysaccharide from Mesonachinensis: Extraction optimization, physicochemical characterizations and antioxidant

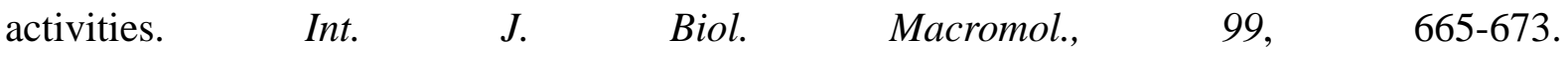
https://doi.org/10.1016/j.ijbiomac.2017.03.040

Liu, J., Wang, C., Wang, Z., Zhang, C., Lu, S., \& Liu, J. (2011). The antioxidant and free-radical scavenging activities of extract and fractions from corn silk (Zea mays L.) and related flavone glycosides. Food. Chem., 126, 261-269. https://doi.org/10.1016/j.foodchem.2010.11.014 
Mengome, L. E., Voxeur, A., Akue, J. P., \& Lerouge, P. (2014). Screening of antioxidant activities of polysaccharides extracts from endemic plants in Gabon. Bioact. Carbohydr. DietFibre, 3(2), 77-88. https://doi.org/10.1016/j.bcdf.2014.02.001

Olabissi, O. A., Moussa, O., Moustapha, O., Edgard, Z. F., Eléonore, K., Marius, L., \& Pierre, G. I. (2011). Acute toxicity and anti-inflammatory activity of aqueous Ethanol extract of root bark of Ximenia americana L. (Olacaceae). Afr. J. Pharm. Pharmacol., 5(7), 806-811. https://doi.org/10.5897/AJPP10.008

Ovodov, I. (1998). Polysaccharides of flower plants: structure and physiological activity. Bioorg. Khim., 24(7), 483-501.

Pereira, L. P., Silva, K. E. S., Silva, R. O., Assreuy, A. M. S., \& Pereira, M. G. Anti-inflammatory polysaccharides of Azadirachta indica seed tegument. (2012b). Rev. Bras. Farmacogn., 3(22), 617-622. https://doi.org/10.1590/S0102-695X2012005000031

Pereira, L.P., Silva, R. O., Bringel, P. H., da Silva, K. E. S., Assreuy, A. M., \& Pereira, M. G. (2012a). Polysaccharide fractions of Caesalpinia ferrea pods: Potential anti-inflammatory usage. J. Ethnopharmacol., 139(2), 642-648, https://doi.org/10.1016/j.jep.2011.12.012

Siddiqui, N., Rauf, A., Latif, A., \& Mahmood, Z. (2017). Spectrophotometric determination of the total phenolic content, spectral and fluorescence study of the herbal Unani drug Gul-e-Zoofa (Nepeta bracteata Benth). J. Taibah Univ. Sci., 12(4), 360-363. https://doi.org/10.1016/j.jtumed.2016.11.006

Silva-Leite, K. E. S. da, Assreuy, A. M. S., Mendonça, L. F., Damasceno, L. E. A., Queiroz, M. G. R. de, Mourão, P. A. S., ... Pereira, M. G. (2017). Polysaccharide rich fractions from barks of Ximenia americana inhibit peripheral inflammatory nociception in mice. Rev. Bras. Farmacogn., 27(3), 339-345. https://doi.org/10.1016/j.bjp.2016.12.001

Silva-Leite, K. E. S., Girão, D. K. F. B., de Freitas Pires, A., Assreuy, A. M. S., de Moraes, P. A. F., Cunha, A. P., ... Soares, P. M. G. (2018). Ximenia americana heteropolysaccharides ameliorate inflammation and visceral hypernociception in murine caerulein-induced acute pancreatitis: Involvement of CB2 receptors. Biomed. Pharmacother, 106, 1317-1324. https://doi.org/10.1016/j.biopha.2018.07.067

Soro, T. Y., Traore, F., \&Sakande, J. (2009). Activité analgésique de l'extrait aqueux de Ximenia americana (Linné) (Olacaceae).C. $R . \quad$ Biologies, 332(4), 371-377. https://doi.org/10.1016/j.crvi.2008.08.022

Sun, H. H., Mao, W. J., Chen, Y., Guo, S. D., Li, H. Y., Qi, X. H., .. Xu, J. (2009). Isolation, chemical characteristics and antioxidante properties of the polysaccharides from marine fungus Penicillium sp. Carbohydr. Polym, 78(1), 117-124. https://doi.org/10.1016/j.carbpol.2009.04.017

Suo, J., Linke, B., Meyer dos Santos, S., Pierre, S., Stegner, D., Zhang, D.D., Denis, ... Scholich, K. Neutrophils mediate edema formation but not mechanical allodynia during zymosan-induced inflammation. (2014). J. Leukoc. Biol., 96(1), 133-142. 
https://doi.org/10.1189//jlb.3A1213-62R

Wang, L., Zhao, D., Di, L., Xu, T., Lin, X., Yang, B., ... Liu, Y. The analgesic and anti-rheumatic effects of Thladian thadubia crude polysaccharide fraction in mice and rats. (2011). J. Ethnopharmacol., 137(3), 1381-1387. https://doi.org/10.1016/j.jep.2011.08.004

Xu, D. P., Li, Y., Meng, X., Zhou, T., Zhou, Y., Zheng, J., ... Li, H. B. (2017). Natural Antioxidants in Foods and Medicinal Plants: Extraction, Assessment and Resources. Int. J. Mol. Sci., 18(1), 96. https://doi.org/10.3390/ijms 18010096

Xu, F., Liao, K., Wu, Y., Pan, Q., Wu, L., Jiao, H., ... Liu, B. (2016). Optimization, characterization, sulfation and antitumor activity of neutral polysaccharides from the fruit of Borojoa sorbiliscuter. Carbohydr. Polym, 151, 364-372. https://doi.org/10.1016/j.carbpol.2016.05.091

Yang, K., Gao, Z. Y., Li, T. Q., Song, W., Xiao, W., Zheng, J., .. Zou, H. Y. (2018). Anti-tumor activity and the mechanism of a green tea (Camellia sinensis) polysaccharide on prostate cancer. Int. J. Biol. Macromol., 122, 95-103. https://doi.org/10.1016/j.ijbiomac.2018.10.101

Zhao, T., Mao, G., Feng, W., Mao, R., Gu, X., Li, T., ... Wu, X. (2014). Isolation, characterization and antioxidante activity of polysaccharide from Schisandra sphenanthera. Carbohydr. Polym, 105, 26-33. https://doi.org/10.1016/j.carbpol.2014.01.059

Zhu, J., Chen, Z., Chen, L., Yu, C., Wei, X., \& Wang, Y. (2019). Comparison and structural characterization of polysaccharides from natural and artificial Se-enrichedgreentea. Int. J. Biol. Macromol. https://doi.org/10.1016/j.ijbiomac.2019.02.102

\section{Copyright Disclaimer}

Copyright for this article is retained by the author(s), with first publication rights granted to the journal.

This is an open-access article distributed under the terms and conditions of the Creative Commons Attribution license (http://creativecommons.org/licenses/by/4.0/). 